\title{
PREDIKSI PERINGKAT OBLIGASI PERUSAHAAN DENGAN PENDEKATAN FAKTOR KEUANGAN DAN NON KEUANGAN
}

\author{
Oleh: \\ Ameilia Damayanti ${ }^{1}$ \\ Sri Ambarwati ${ }^{2}$ \\ Tri Astuti ${ }^{3}$ \\ Universitas Pancasila, Jakarta, Indonesia \\ Email:amel.damay@univpancasila.ac.id ${ }^{l}$
}

\begin{abstract}
ABSTRAK
Penelitian ini bertujuan untuk mengetahui, menganalisis, membuktikan dan menguji pengaruh profitabilitas, likuiditas, leverage, dan umur obligasi terhadap peringkat obligasi pada perusahaan sektor non keuangan yang terdaftar di Bursa Efek Indonesia tahun 2011-2015. Pengambilan sampel menggunakan teknik purposive sampling, dan sampel yang digunakan dalam penelitian ini sebanyak 17 perusahaan sektor non keuangan yang terdaftar di Bursa Efek Indonesia pada tahun 2011 sampai 2015. Metode analisis yang digunakan adalah regresi logistik. Hasil penelitian menunjukkan bahwa profitabilitas (NPM) tidak berpengaruh signifikan terhadap prediksi peringkat obligasi, likuiditas(CR) berpengaruh signifikan terhadap prediksi peringkat obligasi, leverage (DER)tidak berpengaruh signifikan terhadap prediksi peringkat obligasi, dan umur obligasi tidak berpengaruh signifikan terhadap prediksi peringkat obligasi. Pengujian tersebut berdasarkan pada tingkat keyakinan sebesar 95\% dan tingkat eror sebesar 5\%.

Kata Kunci : Profitabilitas (NPM), Likuiditas (CR), Leverage (DER), Umur Obligasi, Peringkat Obligasi, Pefindo
\end{abstract}

\section{A. PENDAHULUAN}

Obligasi bila dibandingkan dengan saham memiliki kelebihan dari sisi keamanannya yaitu pergerakan saham lebih berfluktuatif dibandingkan dengan obligasi dan obligasi memberikan return yang positif serta pendapatan yang tetap. Namunmeskipun lebih aman, obligasi juga mempunyai resiko yaitu resiko gagal bayar (default).

Kasus di Indonesia terjadi pada beberapa emiten yang sebelumnya memiliki peringkat layak investasi (investment grade). Tahun 2009, obligasi gagal bayar (default) terjadi pada PT Mobile -8 Telecom Tbk, telah gagal bayar 2 kali untuk kupon 15 maret 2009 dan 15 juni 2009 yang jatuh tempo pada Maret 2012 dengan obligasi senilai Rp 675 miliar. Selain itu juga ada PT Davomas Abadi Tbk, yang telah gagal bayar sebesar 13,09 juta untuk pembayaran kupon 5 Mei 2009 dengan obligasi senilai 235 juta dolar untuk jatuh tempo tahun 2011 (Kompasiana, 9 Februari 2010). Akibatnya PT Pefindo menurunkan rating perusahaan yang default tersebut. Per Juni 2008 dan 2009, peringkat obligasi PT Mobile 8 Telecom 
Tbk adalah idBBB+. Per Juni 2010, peringkat diturunkan menjadi idD pada Indonesian Bond Market Directory.

PT Pefindo secara umum, dalam menilai peringkat perusahaan meliputi tiga risiko utama penilaian, yang terdiri daririsiko industri (industry risks), risiko bisnis (business risks), dan risiko finansial (financial risks), namun belum ada penjelasan selanjutnya mengenai aspek mana yang lebih diutamakan dalam pemeringkatan dan agen pemeringkat tidak menyebutkan dengan rincibagaimana laporan keuangan digunakan pada menentukan peringkat obligasi. Tujuan penelitian ini adalah menguji salah satu aspek yang digunakan Pefindo dalam penilaian, yaitu aspek keuangan(Damayanti \& Mulyadi, 2014).

Sudah ada beberapa penelitian yang meneliti mengenai peringkat obligasi namun dari penelitian terdahulu masih terdapat hasil yang belum konklusif atau masih berbeda beda seperti halnya (Veronica, 2015), dan (Sihombing \& Rachmawati, 2015) menyimpulkan bahwa profitabilitas tidak berpengaruh pada peringkat obligasi sedangkan (Manurung \& et al, 2008) menyatakan bahwa profitabilitas berpengaruh positif pada peringkat obligasi. Variabel lainnya yaitu likuiditas, dalam penelitian (Sari \& Badjra, 2016) , (Veronica, 2015) menyimpulkan bahwa likuiditas berpengaruh positif pada peringkat obligasi, sedangkan penelitian (Damayanti \& Mulyadi, 2014) menyatakan bahwa likuiditas tidak berpengaruh pada peringkat obligasi. Faktor non keuangan dalam penelitian ini adalah jangka waktu jatuh tempo instrument obligasi (maturity). Umur obligasi (maturity) adalah jangka waktu sejak diterbitkannya obligasi sampai dengan tanggal jatuh tempo obligasi.

Berdasarkan latar belakang masalah yang dipaparkan sebelumnya, penelitian ini akan menguji kemampuan rasio keuangan untuk memprediksi peringkat obligasi. Untuk itu rumusan masalah pada penelitian ini adalah "Bagaimana pengaruh profitabilitas, likuiditas, leverage, dan umur obligasi terhadap peringkat obligasi?"

Tujuan penelitian ini dilakukan untuk mengetahui, menguji, membuktikan dan menganalisis bahwa profitabilitas, likuiditas, leverage, dan umur obligasi berpengaruh terhadap peringkat obligasi. Penelitian ini diharapkan bisa memberikan kontribusi baik langsung maupun tidak langsung. Secara praktis diharapkan penelitian ini bisa digunakan sebagai bahan pertimbangan pengambilan keputusan untuk calon investor dan diharapkan bisa memberikan informasi bagi emiten mengenai faktor-faktor yang berpotensi mempengaruhi peringkat obligasi untuk mengingkatkan kinerja sehingga obligasi yang diterbitkan dapat terus bertahan dan bersaing di pasar modal Indonesia.Hasil penelitian ini juga diharapkan dapat memberikan wawasan pengetahuan \& penelitiandi bidangkeuangan dan pasar modal dan sebagai referensi bagi penelitian sejenis yang meneliti lebih mendalam pada bidang investasi obligasi.

\section{B. KAJIAN PUSTAKA}

\section{Teori Keagenan}

Teori keagenan merupakan versi game theory yang memodelkan proses kontrak antara dua orang atau lebih dan pihak yang terlibat dalam kontrak 
mencoba memperoleh yang terbaik bagi dirinya (Estiyanti \& Yasa, 2012). Teori keagenan intinya adalah antara principal dan agen memiliki kepentingan yang berbeda, masing-masing pihak mementingkan kepentingannya sendiri sehingga timbul konflik.

Menurut (Husnan, 2007)Konflik keagenan yang berhubungan dengan penerbitan obligasi bisa terjadi antara agen yaitu pihak manajemen dengan principal yaitu pihak kreditor. Manajemen yang perusahaannya menerbitkan obligasi berkepentingan agar obligasi yang diterbitkan mampu terjual seluruhnya. Sedangkan para kreditor berkepentingan terhadap penjaminan kondisi perusahaan penerbit obligasi dalam keadaan baik sehingga nantinya tidak mendatangkan kerugian. Untuk mengurangi konflik tersebut maka manajemen menggunakan jasa lembaga pemeringkat obligasi sehingga dalam hal ini dapat mengurangi biaya penjaminan (bonding cost).

\section{Teori Signal}

Teori signal dalam penelitian ini menjelaskan bahwa manajemen perusahaan sebagai pihak yang memberikan signal berupa laporan keuangan perusahaan dan informasi non keuangan kepada lembaga pemeringkat. Lembaga pemeringkat obligasi (Pefindo) ini melakukan proses pemeringkatan sehingga bisa menerbitkan peringkat obligasi bagi perusahaan penerbit obligasi ini. Peringkat obligasi ini memberikan signal atau informasi tentang probabilitas kegagalan pembayaran utang sebuah perusahaan.

\section{Obligasi}

(BEI, 2010) mengartikan obligasi sebagai surat utang jangka menengahpanjang yang dapat dipindahtangankan yang berisi janji dari pihak yang menerbitkan untuk membayar imbalan berupa bunga pada periode tertentu dan melunasi pokok utang pada waktu yang telah ditentukan kepada pihak pembeli obligasi tersebut. Jadi selembar kertas yang menyatakan bahwa pemilik kertas tersebut memberikan pinjaman kepada perusahaan yang menerbitkan surat obligasi disebut dengan surat obligasi.

\section{Peringkat Obligasi}

Peringkat (rating) merupakan pernyataan mengenai keadaan emiten dan kemungkinan apa yang bisa dan akan dilakukan sehubungan dengan utang yang dimiliki, sehingga bisa dikatakan bahwa rating mencoba mengukur risiko default,yaitu keadaan dimana emiten maupun peminjam dana tidak mampu memenuhi kewajibannya. Semakin tinggi peringkat obligasi, semakin menunjukkan bahwa obligasi tersebut terhindar dari risiko gagal bayar (default).

Bagi perusahaan, peringkat bermanfaat untuk mengetahui struktur organisasi dan mengetahui posisi kinerjanya dibanding perusahaan lain. Apabila perusahaan mendapatkan peringkat yang baik, maka bisa dimanfaatkan sebagai sarana promosi dan meningkatkan kepercayaan investor. Hal inidikarenakan perusahaan mempunyai kemampuan untuk membayar obligasi dengan baik. Dengan demikian pemodal yang berinvestasi pada obligasi perusahaan tersebut semakin banyak dan sumber dana yang diperoleh juga semakin besar. Dari sisi 
investornya, adanya agen pemeringkat bisa membantu dalam memberikan informasi investasi tambahan mengenai kemampuan emiten dilihat dari aspek ekonomi dan keuangan. Peringkat dari tiap obligasi yang dilakukan oleh agen pemeringkat (PT. Pefindo) memberikan gambaran tentang kredibilitas (creditworthiness) dan mempengaruhi penjualan obligasi yang bersangkutan.

Beberapa penelitian yang meneliti faktor rasio terhadap prediksi peringkat obligasi menunjukkan hasil yang berbeda. Adapun diantaranya telah dilakukan oleh (Sari \& Badjra, 2016)dengan variabel yang diteliti adalah likuiditas, ukuran perusahaan (size), Solvabilitas (leverage), dan jaminan. Teknik analisis yang dipergunakan pada penelitian ini adalah regresi logistik dengan hasil analisis yang menunjukkan bahwa likuiditas, ukuran perusahaan (Size) serta jaminan berpengaruh signifikan terhadap peringkat obligasi, namu untuk variabel solvabilitas (leverage)tidak berpengaruh secara signifikan.

(Veronica, 2015)meneliti tentang faktor-faktor yang berpengaruh terhadap peringkat obligasi pada perusahaan di sector manufaktur dengan menggunakan variabel profitabilitas, likuiditas, ukuran perusahaan, leverage, serta umur obligasi. Teknik analisis yang digunakan pada penelitian ini adalah regresi berganda dan hasil yang diperoleh adalah likuiditas, size dan umur obligasi berpengaruh terhadap peringkat obligasi sedangkan variabel profitabilitas tidak memiliki pengaruh terhadap peringkat obligasi.

\section{Hubungan antara Profitabilitas dan Peringkat Obligasi}

Profitabilitas yang diproxykan menggunakan rasioNet Profit Margin menunjukan kemampuan perusahaan memperoleh laba dengan penjualan. Hal ini memberikan gambaran seberapa efektif perusahaan beroperasi sehingga memberikan keuntungan bagi perusahaan. Perusahaan yang memiliki Net Profit Margin tinggi akan berperingkat baik karena laba yang dihasilkan dapat digunakan untuk melunasi kewajiban. Menurut(Purwaningsih, 2008), untuk mendapatkan peringkat yang baik dibutuhkan tingkat profitabilitas perusahaan yang tinggi sehingga semakin rendah risiko ketidakmampuan membayarnya (default). Berdasarkan penjelasan tersebut maka hipotesa alternatif dalam penelitian ini bisa dirumuskan menjadi :

$\mathrm{H}_{1}$ : Profitabilitas yang diproxikan dengan Net Profit Margin berpengaruh terhadap peringkat obligasi

\section{Hubungan antara Likuiditas dan Peringkat Obligasi}

Likuiditas yang diproxykan dengan current ratio menjelaskan kewajiban membayar finansial oleh perusahaan dalam jangka pendek. Likuiditas dengan tingkat yang tinggi menandakan pelunasan hutang yang baik. Penelitian (Purwaningsih, 2008)menemukan hubungan yang positif antaralikuiditas dengan credit rating. Agar perusahaan mendapatkan peringkat obligasi yang baik maka perusahaan tersebut harus memiliki tingkat likuiditas yang tinggi. (Almilia \& Devi, 2007)menyatakan bahwa untuk mendapatkan peringkat obligasi yang bagus bisa dilihat dari kondisi keuangan yang kuat yang ditunjukkan dengan tingkat 
likuiditas yang tinggi. Berdasarkan keterangan diatas, hipotesa alternatif dalam penelitian ini menjadi :

$\mathrm{H}_{2}$ : Likuiditas yang diproxikan dengan current ratio berpengaruh terhadap peringkat obligasi

\section{Hubungan antara Leverage dan Peringkat Obligasi}

Leveragemerupakan pengukur tingkat pemakaian hutang pada kegiatan investasi. Jika perusahaan memiliki kesempatan utang makadapat menambah manfaat perusahaan untuk melakukan expansi usaha. Proporsiutang yang baik adalah adanya keseimbangan antara hasil utang dengankemampuan pelunasan kewajiban perusahaan (Damayanti \& Mulyadi, 2014).

Pemakaian rasio Leverage bisa mengecilkan resiko default pada perusahaan apabila leverage tersebut memiliki nilai yang rendah. Hal ini bisa diukur seberapa besar perusahaan membiayai investasinya dengan menggunakan hutang(Magreta \& Nurmayanti, 2009).

Dengan demikian, leverage perusahaan yang rendah bisa memberikan peringkat obligasi yang tinggi.Oleh karena itu hipotesis alternatif dalam penelitian ini bisa dijelaskan menjadi :

$\mathrm{H}_{3}$ : Leverage berpengaruh terhadap peringkat obligasi

\section{Hubungan antara Umur Obligasi dan Peringkat Obligasi}

Umur obligasi (maturity) merupakan deadline atau tanggal waktu pemegang obligasi akan mendapatkan pembayaran kembali nilai nominal obligasi yang dimilikinya atau pokok yang dipinjamkannya. Periode pembayaran kembali (jatuh tempo) obligasi bervariasi mulai dari satu sampai dengan di atas lima tahun.

Biasanya semakin tinggi kupon atau bunga yang didapatkan dari suatu obligasi diperoleh dari semakin panjang jatuh tempo suatu obligasi tersebut (BEI, 2010).Berdasarkan penjelasan yang telah diuraikan, maka hipotesis alternatif dalam penelitian ini dapat dibuat menjadi :

$\mathrm{H}_{4}$ : Umur obligasi berpengaruh terhadap peringkat obligasi

Dari keseluruhan teoritik tentang pengaruh profitabilitas, likuiditas, leverage, dan ukuran perusahaan terhadap prediksi peringkat obligasi yang telah dipaparkan di atas, maka dapat dibuat suatu kerangka pemikiran yang dapat digambarkan sebagai berikut : 


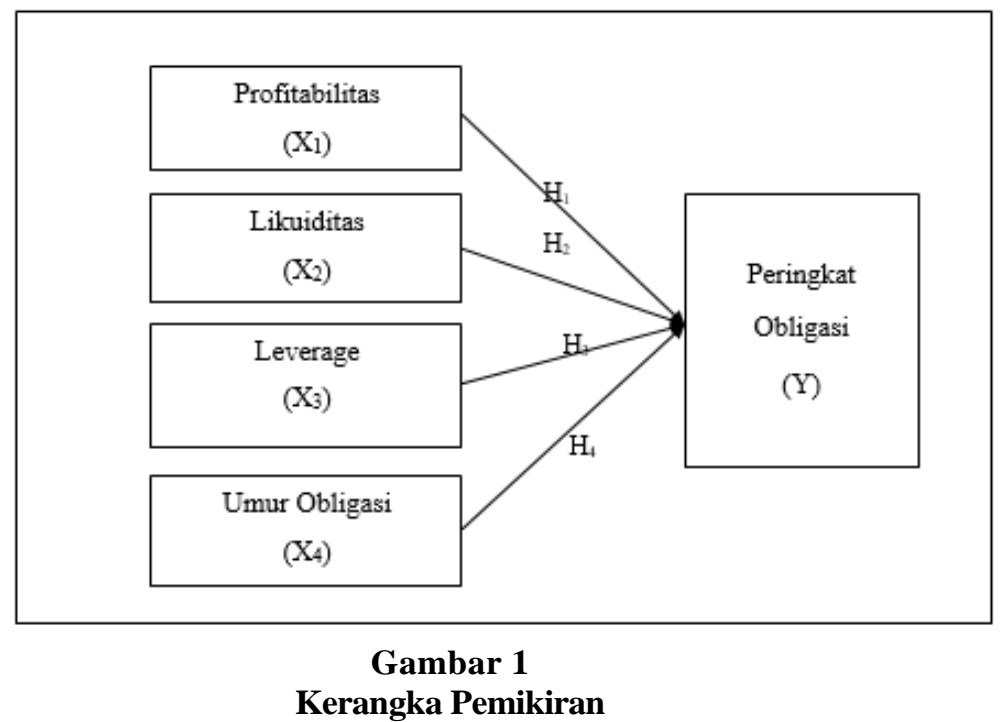

\section{METODE PENELITIAN}

Jenis penelitian adalah penelitian kuantitatif yang mana data kuantitatif tersebut adalah data sekunder. Data sekunder yang digunakan berupa data laporan keuangan auditan emiten yang pada BEI periode 2011-2015 dalam Indonesian Capital Market Directory (ICMD), data dalam Indonesian Bond Market Directory (IBMD), serta data pemeringkatan obligasi dari PT. Pefindo.

Populasi dalam penelitian ini yaitu perusahaan sektor nonkeuangan yang mengeluarkan obligasi dan terdaftar di BEI (Bursa Efek Indonesia) sejak tahun 2011 sampai 2015. Kemudian metode purposive sampling menjadi pemilihan sampel pada penelitian ini. Metode pengumpulan data yang dilakukan pada penelitian ini adalah metode dokumentasi,yaitu data yang diperoleh dari berbagai dokumen. Selain itu juga menggunakan metode observasi yang peneliti hanya mengamati secara independen dan tidak terlibat secara langsung. Terdapat dua macam variabel dalam penelitian ini yaitu variabel terikat dan variabel independen.

Variabel terikat atau biasa disebut dependen pada penelitian ini adalah peringkat obligasi. Untuk memudahkan dalam pengolahan data mengingat adanya keterbatasan data peringkat obligasi dengan kategori non-investment grade (BB atau lebih rendah) maka peneliti melakukan modifikasi terhadap klasifikasi skala peringkat obligasi. Penelitian ini berbeda dari penelitian sebelumnya karena pada penelitian ini memakai kriteria obligasi dengan high investment grade (AAA, AA, A) dan low investment grade (BBB). Pada variabel ini mengukur tingkat peringkat obligasi perusahaan industri non keuangan dengan mengacu pada penelitian terdahulu oleh (Magreta \& Nurmayanti, 2009).

Variabel tidak terikat atau biasa disebut independen pada penelitian ini ada empat varibel yang terdiri dari Profitabilitas, Likuiditas, Leverage dan Umur Obligasi. Pertama yaitu variabel profitabilitas, rasio ini merupakan rasio untuk menilai kemampuan perusahaan dalam mencari keuntungan. Rasio ini juga 
memberikan ukuran tingkat efektivitas manajemen suatu perusahaan. Rasio ini dapat diukur dengan Net Profit Margin (NPM).

Kedua yaitu variabel Likuiditas yang merupakan kemampuan perusahaan dalam melunasi kewajiban jangka pendek perusahaan. Variabel likuiditas sebagai variabel independen kedua dalam penelitian ini dihitung dengan current ratio (CR). Menurut (Almilia \& Devi, 2007)perusahaan yang bisa melunasihutangnya tepat waktu adalah perusahaan yang likuid dan memiliki hutang lancar yang lebih kecil daripada aset lancar. Current ratio (CR) adalah perbandingan dari aktiva dan kewajiban lacar.

Kemudian variabel leverage, variabel ini digunakan untuk mengukur keseimbangan proporsiantara asetyang didanai dari kreditor (utang) dan yang didanai oleh pemilik perusahaan(ekuitas). Variabel leverage dihitung menggunakanDebt to Equity Ratio (DER).

Variabel independen keempat yaitu Umur obligasi (maturity) yang merupakan periode penerimaan kembali atau pemegang obligasi yang akan menerima kembali nilai nominal obligasi atau obligasi pokok yang dimilikinya. Periode jatuh tempo obligasi bervariasi mulai dari satu sampai dengan di atas lima tahun. Biasanya semakin tinggi kupon atau bunga yang didapatkan dari suatu obligasi diperoleh dari semakin panjang jatuh tempo suatu obligasi tersebut (BEI, 2010).

Pengujian terhadap hipotesis dalam penelitian ini dilakukan dengan analisis multivariate menggunakan regresi logistik (logistic regression). Model ini digunakan karena variabel dependen dari penelitian ini merupakan variabel dummy. Teknik analisis ini tidak memerlukan lagi uji normalitas dan uji asumsi klasik pada variabel bebasnya (Ghozali, 2013).

1. Statistik Deskriptif

Untuk memberikan gambaran deskripsi suatu data yang dilihat dari rata-rata (mean), standar deviasi, varian, maksimum, minimum digunakan Statistik Deskriptif (Ghozali, 2013).

2. Pengujian Hipotesis

Menurut Buku (Ghozali, 2013) ada beberapa tahap untuk melakukan pengujian dengan menggunakan uji regresi logistik (logistic regression) yang dapat dijelaskan sebagai berikut:

a. Menilai Kelayakan Model Regresi

Output dari Hosmer dan Lemeshow, dengan hipotesis:

Ho : Model yang dihipotesiskan fit dengan data

Ha : Model yang dihipotesiskan tidak fit dengan data

Dasar pengambilan keputusan adalah sebagai berikut:

Nilai goodness of fit test yang diukur dengan nilai chi-square pada bagian bawah uji Hosmer dan Lemeshow.

- Jika probabilitas $>0,05$ maka Ho diterima dan Ha ditolak

- Jika Probabilitas <0,05 maka Ho ditolak dan Ha diterima

b. Menilai Keseluruhan Model

Menilai angka -2 log likelihood pada awal (blok number $=0$ ) dan angka -2 log likelihood pada blok number $=1$, jika terjadi penurunan angka -2 log likelihood maka menunjukkan model regresi yang baik. 
Log likelihood pada regresi logistik mirip dengan pengertian "sum of squared error" pada model regresi, sehingga penurunan log likelihood menunjukkan model regresi yang baik.

c. Nagel Karke

Nagel Karke R Square merupakan modifikasi dari koefisien Cox dan Snell's untuk memastikan bahwa nilainya bervariasi dari 0 sampai 1. Hal ini dilakukan dengan cara membagi nilai Cox dan Snell's $\mathrm{R}^{2}$ dengan nilai maksimumnya. Nilai Nagel Karke $\mathrm{R}^{2}$ dapat diinterprestasikan seperti nilai $\mathrm{R}^{2}$ pada multiple regression.

d. Uji Hipotesis

Analisis ini dilakukan untuk menentukan pengaruh dari masingmasing variabel bebas (independen variabel) terhadap variabel terikat (dependen variabel) yaitu prediksi peringkat obligasi perusahaan industri non keuangan tahun 2011 sampai tahun 2015, karena variabel terikatnya merupakan variabel dummy yaitu variabel yang memiliki dua alternatif. Adapun model hipotesisnya adalah sebagai berikut :

$\operatorname{Ln} \frac{p}{1-p}=\alpha+\beta_{1} X_{1}+\beta_{2} X_{2}+\beta_{3} X_{3}+\beta_{4} X_{4}+e$

Keterangan :

$\mathbf{L n} \frac{p}{1-p}=\mathbf{1}$, jika peringkat obligasi termasuk highinvestment grade

$\mathbf{L n} \frac{p}{1-p}=\mathbf{0}$, jika peringkat obligasi termasuk low investment grade

$\boldsymbol{\alpha}$ : Konstanta

及1-3: Koefisien regresi

$\mathbf{X}_{1}$ : Net Profit Margin (NPM)

$\mathbf{X}_{2}:$ Current Ratio $(C R)$

$\mathbf{X}_{\mathbf{3}}:$ Debt on Equity (DER)

$\mathbf{X}_{\mathbf{4}}$ : Umur Obligasi

e : Standard Error

\section{HASIL DAN PEMBAHASAN}

Perusahaan yang listing dan terdaftar di Bursa Efek Indonesia dan memiliki obligasi yang diberi peringkat oleh PT. Pefindo merupakan populasi dalam penelitian ini. Metode penentuan sampel dalam penelitian ini adalah metode purposive sampling yang mensyaratkan kriteria-kriteria tertentu, beberapa diantaranya adalah perusahaan sektor non keuangan, memiliki laporan keuangan lengkap tahun 2011 hingga 2015 dan obligasi yang terbit dan beredar pada tahun 2011-2015.Jumlah perusahaan sampel adalah 17 perusahaan, maka terdapat 85 sampel selama 5 tahun. 
Tabel 1

Descriptive Statistics

\begin{tabular}{|l|r|r|r|r|r|}
\hline & $\mathrm{N}$ & $\begin{array}{c}\text { Minimu } \\
\mathrm{m}\end{array}$ & $\begin{array}{c}\text { Maximu } \\
\mathrm{m}\end{array}$ & \multicolumn{1}{c|}{ Mean } & $\begin{array}{c}\text { Std. } \\
\text { Deviation }\end{array}$ \\
\hline NPM & 85 & .11 & 71.73 & 13.3962 & 12.81681 \\
CR & 85 & .37 & 2.76 & 1.4034 & .59485 \\
DER & 85 & .22 & 7.87 & 1.6566 & 1.26856 \\
Valid N & 85 & & & & \\
(listwise) & & & & & \\
\hline
\end{tabular}

Berdasarkan tabel Descriptive Statistics dapat dilihat bahwa dalam penelitian ini digunakan sampel sejumlah 85 sampel dari 17 perusahaan non keuangan dikali dengan waktu pengamatan selama 5 tahun dari 2011-2015.

\section{Menilai Kelayakan Model Regresi}

Kelayakan model regresi dinilai dengan menggunakan Goodness of Fit test. Goodness of Fit Test menguji kesesuaian model antara hipotesis nol sebagai data hasil prediksi model dengan data empiris (tidak ada perbedaan antara model dengan data sehingga model dikatakan fit). (Ghozali,2013).

Tabel 2

Hosmer and Lemeshow Test

\begin{tabular}{|l|r|r|r|}
\hline Step & Chi-square & df & \multicolumn{1}{|c|}{ Sig. } \\
\hline 1 & .842 & & 7 \\
\hline
\end{tabular}

Tabel menunjukkan nilai statistik Hosmer and Lemeshow sebesar 0,842 dengan probabilitas signifikansi 0,997 maka lebih besar dari 0,05 sehingga Hoditerima. Hal ini berarti bahwa model yang terbentuk adalah fit atau layak digunakan dalam regresi logistik.

Menilai Keseluruhan Model Pengujian ini akan menguji pengaruh dari masing-masing variabel independen yaitu Net Profit Margin (NPM), current ratio (CR) dan umur obligasi terhadap peringkat obligasi. Pengujian ini dilakukan dengan membandingkan nilai antara -2 Loglikehood awal (blok number $=0$ ) dengan -2 Loglikehood pada blok number $=1$. Adanya pengurangan nilai antara 2 Loglikehood awal (blok number $=0$ ) dengan nilai -2 Loglikehood pada blok number $=1$ menunjukkan bahwa modelregresi yang baik.

Pada tabel diatas menunjukkan hasil uji goodness of fit terlihat nilai signifikansi Pearson 0,766, lebih besar dari 0,05 yang berarti bahwa model fit dengan data atau dapat memprediksi nilai observasinya dengan baik. 
Tabel 3

Iteration History ${ }^{\mathrm{a}, \mathrm{b}, \mathrm{c}}$

\begin{tabular}{|ll|r|r|}
\hline & & & Coefficients \\
\cline { 4 - 4 } Iteration & & -2 Log likelihood & \multicolumn{1}{|c|}{ Constant } \\
\hline Step 0 & 1 & 40,218 & 1,812 \\
& 2 & 33,036 & 2,585 \\
& 3 & 32,278 & 2,939 \\
& 4 & 32,260 & 3,006 \\
& 5 & 32,260 & 3,008 \\
& 6 & 32,260 & 3,008 \\
\hline
\end{tabular}

Sumber: output SPSS

Model Summary

\begin{tabular}{|l|c|c|c|}
\hline Step & $\begin{array}{c}-2 \text { Log } \\
\text { likelihood }\end{array}$ & $\begin{array}{c}\text { Cox \& Snell R } \\
\text { Square }\end{array}$ & $\begin{array}{c}\text { Nagelkerke R } \\
\text { Square }\end{array}$ \\
\hline 1 & $15.212^{\mathrm{a}}$ & .182 & .575 \\
\hline
\end{tabular}

a. Estimation terminated at iteration number 10 because parameter estimates changed by less than .001 .

Angka -2 log likelihood pada block number $=1$ sebesar 15,212sedang pada block number $=0$ sebesar 32,260. Artinya nilai -2 log likelihoodpada block number $=$ Odan nilai -2 log likelihood pada block number $=1$ mengalami penurunan. Sehingga dapat disimpulkan bahwa model pada persamaanlogistik dalam penelitian ini merupakan model regresi yang lebih baik.

Nagel Kerke. Nilai Nagel Kerke digunakan untuk mengukur seberapa jauh kemampuan model variabel bebas secara bersama-sama dalam menerangkan variasi variabel terikat.

Tabel 4

Model Summary

\begin{tabular}{|r|r|}
\hline $\begin{array}{c}\text { Cox \& Snell R } \\
\text { Square }\end{array}$ & $\begin{array}{c}\text { Nagelkerke R } \\
\text { Square }\end{array}$ \\
\hline, 182 &, 575 \\
\hline
\end{tabular}

Sumber: output SPSS

Dari Tabel 4 dapat dijelaskan hasil uji regresi logistik didapat Cox \& Snell $R$ Square sebesar 0,182 dan Nagelkerke $R$ Square sebesar 0,575. Nilai Cox \& Snell $R$ Square sebesar 0,182 tidak digunakan karena didasarkan pada teknikestimasi likelihood dengan nilai maksimum kurang dari 1 (satu) sehingga sulitdiinterprestasikan. Nilai Nagelkerke $R$ Square sebesar 0,575 berarti bahwa adakontribusi sebesar $57,5 \%$ variabel profitabilitas, likuiditas, leveragedan umurobligasi dalam memprediksi peringkat obligasi secara bersama-sama. 
Sedangkansisanya sebesar $42,5 \%$ dipengaruhi oleh sebab-sebab yang lain di luar variabelyang diteliti.

Uji Hipotesis.Pada pengujian ini dilakukan dengan derajat kebebasan sebesar 5\% atau 0,05, agar kemungkinan terjadinya gangguan kecil dan umum digunakan. Hasil pengujian hipotesis dengan menggunakan regresi logistik disajikan dalam tabel 4.14 berikut ini :

Tabel 5

Hasil uji Regresi Logistik

\begin{tabular}{|ll|r|r|r|r|r|}
\hline & & & & & \\
\hline Step $1^{\mathrm{a}}$ & \multicolumn{1}{c|}{ B } & \multicolumn{1}{c|}{ S.E. } & Wald & df & \multicolumn{1}{c|}{ Sig. } \\
& Profitabilitas & -.001 & .059 & .000 & 1 & .986 \\
& Likuiditas & 9.521 & 4.361 & 4.768 & 1 & .029 \\
\cline { 2 - 7 } & Leverage & .344 & 1.358 & .064 & 1 & .800 \\
\cline { 2 - 7 } & Maturity & 1.894 & 1.150 & 2.714 & 1 & .099 \\
\cline { 2 - 7 } & Constant & -15.026 & 8.664 & 3.008 & 1 & .083 \\
\hline
\end{tabular}

Berdasarkan hasil uji dengan regresi logistikdiketahui bahwa variabel independen yang berpengaruh signifikan terhadap peringkat obligasi hanya likuiditas (current ratio).Berdasarkan tabel 4.5 maka diperoleh persamaan regresi sebagai berikut :

$$
\operatorname{Ln} \frac{p}{1-p}=-15,026-0,001 \mathrm{NPM}+9,521 \mathrm{CR}+0,344 \mathrm{DER}+1,894 \mathrm{UO}
$$

\section{Pengaruh Profitabilitas terhadap Peringkat Obligasi}

Berdasarkan hasil penelitian yang telah dilakukan dengan analisis regresi logistik menunjukkan bahwa profitabilitas perusahaan yang diukur dengan Net Profit Margin tidak berpengaruh signifikan terhadap peringkat obligasi. Hal tersebut didasarkan pada hasil analisis regresi logistik yang memberikan informasi bahwa variabel profitabilitas memiliki nilai signifikansi sebesar 0,986 ( $p>0,05)$ maka $\mathrm{H}_{1}$ ditolak. Dengan begitu maka dapat disimpulkan bahwa profitabilitas tidak berpengaruh signifikan terhadap peringkat obligasi. Alasan yang mendukung hasilriset ini adalah pengukuran profitabilitas yang berdasarkan proksi NPM kurangtepat. Ini dikarenakan hasil perbandingan Earning After Tax dengan penjualan bersih. Disamping itu NPM belum menggambarkan performa keuangan perusahaan secara utuh karena profit yang ada pada NPM hanya sekedar dari penjualan bersih saja. Jika dilihat dari sisi akun penjualan bersih, barang persediaan yang telah terjual bisa saja masih berbentuk account receivable (piutang). Account receivable (piutang) apabila tertagih maka akan menjadi pendapatan ke kas dan bisa menunjang perusahaan untuk membayar hutang jangka pendek maupun jangka panjangnya. Namun apabila account receivable (piutang) tidak tertagih maka profit pada penjualan hanya bersifat semu karena tidak terlaksananya perputaran piutang yang baik sehingga dapat menimbulkan beban piutang tak tertagih. Jadi besarnya penjualan tidak bisa dijadikan sebagai jaminan bahwa perusahaan memiliki kemampuan yang baik dalam melunasi 
hutangnya. Bagi calon investor sebaiknya mengabaikan sinyal tentang profitabilitas perusahaan.

\section{Pengaruh Likuiditas terhadap Peringkat Obligasi}

Berdasarkan hasil penelitian yang telah dilakukan dengan analisis regresi logistik menunjukkan bahwa likuiditas perusahaan yang diukur dengan current ratio berpengaruh signifikan terhadap prediksi peringkat obligasi. Hal tersebut didasarkan pada hasil analisis regresi logistik yang memberikan informasi bahwa variabel likuiditas memiliki nilai signifikansi sebesar $0,029(\mathrm{p}<0,05)$ maka $\mathrm{H}_{2}$ diterima. Dengan begitu maka dapat disimpulkan bahwa likuiditas berpengaruh signifikan terhadap peringkat obligasi. Tingkat likuiditas yang tinggi akan menunjukkan kuatnya kondisi keuangan perusahaan sehingga secara financial akan mempengaruhi peringkat obligasi, karena perusahaan yang mampu melunasi kewajiban jangka pendek mengindikasikan bahwa perusahaan dalam keadaan likuid.

Current ratio menunjukkan kemampuan perusahaan untuk membayar utang jangka pendek dengan aktiva lancarnya. Dengan demikian, apabila likuiditas perusahaan bagus berarti perusahaan mampu untuk membayar utang yang akan segera jatuh tempo dengan aktiva lancar yang dimilikinya. Sementara itu, peringkat obligasi menunjukkan risiko obligasi tersebut. Risiko terkait dengan kemampuan perusahaan yang mengeluarkan obligasi tersebut untuk membayar pokok pinjaman dan bunga pada saat jatuh tempo. Dengan demikian berarti semakin baik rasio likuiditas, semakin rendah risiko perusahaan tidak mampu membayar pokok pinjaman dan bunga yang akan jatuh tempo. Rasio lancar ini juga berhubungan langsung dengan bagaimana suatu perusahaan dapat memenuhi kewajibannya. Selain itu diterimanya hipotesis kedua dalam penelitian ini sesuai dengan salah satu perhatian PEFINDO yang melihat kinerja keuangan suatu perusahaan berdasarkan rasio keuangan yang mencerminkan kualitas aktivanya. Hal ini mengindikasikan bahwa informasi currentratio yang ada pada laporan keuangan perusahaan penerbit obligasi benar-benar bermanfaat untuk investor dan agen pemeringkat dalam memberikan peringkat obligasi perusahaan.

\section{Pengaruh Leverage terhadap Peringkat Obligasi}

Berdasarkan hasil penelitian yang telah dilakukan dengan analisis regresi logistik menunjukkan bahwa leverage perusahaan yang diukur dengan debt to equity ratio tidak berpengaruh signifikan terhadap peringkat obligasi. Hal tersebut didasarkan pada hasil analisis regresi logistik yang memberikan informasi bahwa variabel leverage memiliki nilai signifikansi sebesar $0,800(p>0,05)$ maka $\mathrm{H}_{3}$ ditolak. Hasil pengujian menunjukkan bahwa hipotesis 3 tidak berhasil didukung karena leverage tidak memiliki pengaruh yang signifikan terhadap kemungkinan obligasi memperoleh peringkat kategori yang tinggi. Hal ini dapat diartikan bahwa besar kecilnya leverage perusahaan tidak akan mempengaruhi peringkat obligasi. Menurut(Estiyanti \& Yasa, 2012) hasil yang tidak signifikan mungkin disebabkan oleh perhitungan leverage dalam penelitian ini menggunakan debt to equityratio dimana hutang obligasi masuk dalam rasio tersebut dan tidak dipisahkan dengan total hutang sedangkan perusahaan pemeringkat mungkin hanya menggunakan current liabilities dalam perhitungan leverage. 


\section{Pengaruh Umur Obligasi terhadap Peringkat Obligasi}

Hasil penelitian menyatakan bahwa umur obligasi tidakberpengaruh terhadap peringkat obligasi. Hasil pengujian regresi menunjukkan bahwa umur obligasimemiliki tingkat signifikansi 0,099 artinya dapat disimpulkan bahwa $\mathrm{H}_{4}$ tidak berhasil didukung, sehingga hipotesis 4 ditolak. Hasil pengujian menunjukkan bahwa hipotesis 4 tidak berhasil didukung karena umur obligasitidak memiliki pengaruh yang signifikan terhadap kemungkinan obligasi memperoleh peringkat kategori yang tinggi. Hasil dari analisis menyimpulkan bahwa jatuh tempo umur obligasi tidak mempengaruhi probabilitas kenaikan peringkat obligasi karena dalam hal ini PT. Pefindo memberikan peringkat obligasi perusahaan ditinjau dari kinerja perusahaan dalam membayar hutangnya, dan bukan dilihat dari umur obligasi yang diterbitkan oleh perusahaan. Dari hasil observasi data umur obligasi perusahaan tersebut memiliki umur obligasi yang lebih dari periode akuntansi (satu tahun), karena semakin lama umur obligasi, berarti ada kecenderungan perusahaan tidak bisa membayar bunga atau pokok hutangnya. Jadi umur obligasi tidak terlalu diperhitungkan dalam pemeringkatan obligasi yang dilakukan oleh PT. Pefindo.

\section{E. SIMPULAN}

Berdasarkan hasil uji hipotesis dan pembahasan hasil penelitian yang telah diuraikan, penelitian ini menyimpulkan bahwa likuiditas berpengaruh terhadap peringkat obligasi, sedangkan profitabilitas, leverage danumur obligasi tidak berpengaruh terhadap peringkat obligasi.

\section{DAFTAR PUSTAKA}

Almilia, L., \& Devi, V. (2007). Faktor-faktor yang mempengaruhi prediksi peringkat Obligasi pada perusahaan Manufaktur yang Terdaftar di Bursa Efek Jakarta. Seminar Nasional Manajemen SMART.

BEI. (2010). Mengenal Obligasi. Retrieved from Indonesia Stock Exchange Bursa Efek Indonesia: http://www.idx.co.id

Damayanti, A., \& Mulyadi, J. (2014). Profitabilitas, Likuiditas, Leverage, Ukuran Perusahaan dan Prediksi Peringkat Obligasi pada Perusahaan Sektor Non

Keuangan di Bursa Efek Indonesia. Jurnal Riset Akuntansi dan Perpajakan.

Estiyanti, N. M., \& Yasa, G. W. (2012). PENGARUH FAKTOR KEUANGAN DAN NON KEUANGAN PADA PERINGKAT OBLIGASI DI BURSA EFEK INDONESIA. Jurnal Bisnis dan Ekonomi Universitas Udayana.

Ghozali, I. (2013). Analisis Multivariate Lanjutan dengan Program SPSS. Semarang: Badan Penerbit Universitas Diponegoro.

Husnan, S. (2007). Manajemen Keuangan Teori dan Penerapan (Keputusan Jangka Panjang). Yogyakarta: BPFE. 
Magreta, \& Nurmayanti, P. (2009). Faktor-Faktor yang Mempengaruhi Prediksi Peringkat Obligasi Ditinjau dari Faktor Akuntansi dan Non Akuntansi. Jurnal Bisnis dan Akuntansi Vol.11 No.3, 143-154.

Manurung, A. H., \& et al. (2008). Hubungan Rasio-Rasio Keuangan dengan Rating.

Purwaningsih, A. (2008). Pemilihan Rasio Keuangan untuk Memprediksi Peringkat Obligasi: Studi pada Perusahaan Manufaktur yang Terdaftar di BEJ. Kinerja Vo. 12 No.1, 85-99.

Sari, N. S., \& Badjra, I. B. (2016). PENGARUH LIKUIDITAS, UKURAN PERUSAHAAN, LEVERAGE DAN JAMINAN TERHADAP PERINGKAT OBLIGASI PADA SEKTOR KEUANGAN. Jurnal Manajemen Universitas Udayana Vol. 5 No.8, 5041-5069 pdf.

Sihombing, H. J., \& Rachmawati, E. N. (2015). Faktor-Faktor Yang Mempengaruhi Peringkat Obligasi Pada Perusahaan yang Terdaftar Di Bursa Efek Indonesia. Jurnal Ejonomi Manajemen dan Akuntansi I Vo. 24 No.1, 95-118.

Veronica, A. (2015). FAKTOR-FAKTOR YANG MEMPENGARUHI PERINGKAT OBLIGASI PADA PERUSAHAAN MANUFAKTUR. Jurnal Manajemen dan Bisnis Sriwijaya Vo.13 No.2. 